\title{
Analysis of Factors Affecting Financial Well Being Millennial Generation in Batam
}

\author{
Yandi Suprapto, Meilinda Cecilia \\ ${ }^{1}$ Manajemen, Universitas Internasional Batam, Kota Batam \\ email: yandi.suprapto@uib.ac.id \\ ${ }^{2}$ Manajemen, Universitas Internasional Batam, Kota Batam \\ email: meilindacecilia8@gmail.com
}

\begin{abstract}
The purpose of this study is todetermine whether financial behavior, financial socialization agents,financial attitude, financial stress, and financial literacy can influence financial well being in millennial generation in Batam City. Financial well being is described when a person is able to prosper in the field of financial finance. Welfare is reflected in the ability to meet and manage all needs and desires. While millennial is the most current generation so that it can be a hope and reflection of a country. This research method begins with the distribution of questionnaires to the people of Batam city aged 15-19 years.

Data were collected as many as 300 respondents then processed with multiple regression research models using SPSS.Variable financial literacy, financial attitude and financial socialization agents provide a significant positive relationship to financial well being. Meanwhile financial stress has a significant negative relationship with financial well being. Then for financial behavior variables show no significant relationship to financial well being.
\end{abstract}

Kata Kunci: financial literacy,financial wellbeing, financial attitude, financial socialization agents,financialbehavior and financial stress.

\section{INTRODUCTION}

In this rapidly developing era, many technologies and factors cause a person's level of economic needs to increase. Financial well being is a condition where a person is able to meet his needs for the long term and have financial satisfaction and prosperity. According to the Otoritas Jasa Keuangan (2016), someone who has financial literacy and high financial inclusion will bring that person to a higher level of financial well being. Financial literacy is how a person is able to manage his finances well and is able to make financial decisions well. Whereas financial inclusion is how capable the community is in accessing financial services such as insurance and banking. According to the Otoritas Jasa Keuangan (2016) in 2016, the level of financial literacy in Indonesia was $29.7 \%$ and financial inclusion was $67.7 \%$ and the level of financial literacy in Batam was
$37.1 \%$ and financial inclusion was $74.5 \%$. The condition of millennial generation in Batam is still relatively inexperienced in managing personal finances. This is due to the lack of information obtained on how to manage finances well from the family and from the school.

Achievement of financial literacy and good inclusion can bring someone to financial well being. A person's behavior and habits in managing income also influence the achievement towards financial satisfaction. A person's habits in paying obligations, making purchases or making large-scale expenses and the use of credit cards are also very helpful to control and avoid excessive spending. Such actions are an example of financial behavior. This causes a relationship between financial behavior with financial well being.

The condition when someone feels burdened by obligations is also a factor 
that is able to influence one's financial well being. Financial stress is a situation where an individual is worried about his finances such as in the form of pressure that comes from debt, unable to meet obligations. The higher the financial stress, the lower the financial well being. These two variables will always contradict each other so that it causes financial stress to affect financial well being.

A person's thoughts, opinions and judgments about finances will also affect one's level of financial well being. For example in assessing a financial product that suits the needs of each individual is able to influence financial well being. Choosing a financial product well can help reduce the time and use of the wrong product and result in losses. Such actions constitute a person's attitude in handling finances called financial attitude. This causes that there is a relationship between financial attitude with financial well being.

Financial socialization agents also have an effect on improving financial well being. Financial socialization agents consist of primary and secondary agents where primary agents are influences from the inner environment, namely from parents and secondary agents are influences from the outside environment such as from peers and social media such as newspapers and the internet. The influences from the surrounding environment tend to reflect what an individual will do in the future.

\section{RESEARCH FRAMEWORK AND HYPOTHESIS DEVELOPMENT}

Research conducted by Setiyani and Solichatun (2019) with the aim of examining the effect of financial behavior, financial socialization agents, financial attitude, financial stress, and financial literacy on financial well being. This study tests the financial behavior that is tested as being two types of variables, namely as an independent variable and a mediating variable so that in this study conducted two tests. This research was distributed to 536 students at the University of Semarang in 2015, especially to the economic faculty of financial focus and processed through the SPSS system.

Nandan and Saurabh (2019) examined a study which examined financial knowledge, financial socialization agents and financial risk attitudes on financial well being. There are two independent variables namely financial knowledge and financial socialization along with mediating variables namely financial risk attitude and the dependent variable financial well being. This research was conducted by distributing questionnaires to 350 investors and returning 317 respondents with 286 respondents who could be used due to lack of data. The questionnaire distributed was based on five points, which scaled from strongly disagree to strongly agree, which was then processed using the SPSS system. This research was carried out in India specifically in the city called Allahabad in the central area of Uttar Pradesh, India.

Research conducted by Younas, Javed, Kalumuthu, Farooq, and Rehman (2019) explains that there is a relationship between self control, financial literacy, and financial behavior towards financial Well Being. This study involved 600 respondents by getting 416 valid respondents conducted in Pakistan. This study uses three independent variables in the form of self control, financial literacy, and financial behavior with one independent variable, financial well being. This study uses SPSS to process the questionnaire respondents. The questionnaire they did was based on five points which meant consisting of strongly disagreeing, disagreeing, neutral, agreeing and strongly agreeing. They collected data from various regions such as educational institutions, the corporate sector and 
places to eat in Pakistan. They made the questionnaire with Google forms and selected respondents' data through G.power software.

Research conducted by Arifin (2018) with the aim of understanding and testing the financial attitude and financial knowledge of financial well being of employees in Jakarta. The study uses two independent variables namely financial knowledge and financial attitude with one dependent variable, financial well being. This study uses a questionnaire distribution to 450 respondents from various sectors of workers in Jakarta consisting of students who are working and graduating. The questionnaire was designed through a Google form that was shared through social media such as Facebook, WhatsApp and email. The majority of respondents in this study were people who were actively working on an age scale from 20 to 40 years with a percentage of $73.4 \%$ and $96.2 \%$ of respondents were people who worked in a private place. The majority of respondents in this study were also graduates from universities as many as $62.2 \%$ of respondents were processed by SPSS software.

Financial well being is explained as a condition where someone has been able to meet financial obligations and have financial preparation in the future according to the Financial Services Authority (2017). According to Setiyani and Solichatun (2019) states financial well being is a condition where a person is in health, pleasure and is not worried about finances or finances based on one's own views. According to the Consumer Financial Protectoin Bureau (2015), financial well being consists of 4 concepts: financial control for the short and long term, having the ability to deal with financial shock, being able to achieve financial goals and being able to achieve financial freedom to find a better life.
Financial literacy is considered to have a significant positive effect on financial well being because of the existence of a financial literacy attitude such as being able to manage its finances well and take financial decisions well being able to make one's financial well being better.Financial behavior is considered to have a significant positive influence on financial well being because one's habits in handling finances will affect one's financial well being level.Financial stress is considered to have a significant negative effect because someone who is experiencing financial pressure tends to be less able to run financial well being well.Financial attitude is considered to have a significant positive effect because with the intellectual attitude in handling finances will improve one's financial well being because they have thoughts and targets to be achieved.Financial socialization agents are considered to have a significant positive effect because humans tend to frequently ask for opinions and obtain financial knowledge both in terms of internal (family) and external aspects (peers, internet or lectures).

The formulation of the research model and hypothesis in this study are as follows:

$\mathrm{H}_{1}$ : Financial literacy has a significant positive effect on financial well being in millennials in Batam City

$\mathrm{H}_{2}$ : Financial behavior has a significant positive effect on financial well being in millennials in Batam City

$\mathrm{H}_{3}$ : Financial stress has a significant negative effect on financial well being on millennial generation in Batam City

$\mathrm{H}_{4}$ : Financial attitude has a significant positive effect on financial well being in millennials in Batam City

$\mathrm{H}_{5}$ : Financial socialization agents have a significant positive effect on financial well being in millennial generation in Batam City. 


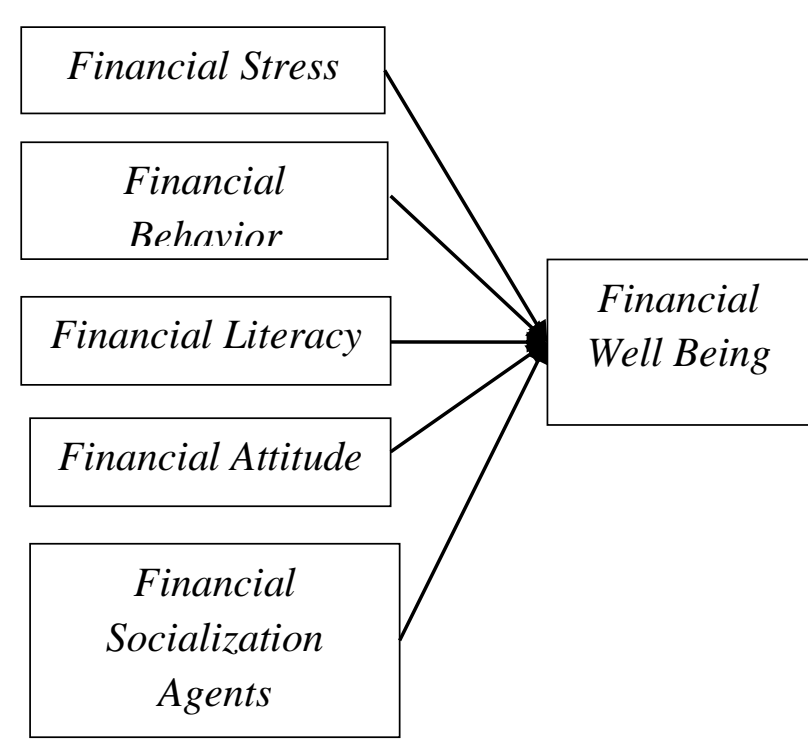

This research is a quantitative research using direct and indirect data collection methods. The direct method will be carried out by distributing questionnaires directly to prospective respondents and indirectly utilizing the "Google Form" instrument sent via the link.

The object of research taken was millennial generation in Batam City, ranging in age between 15-39 years. The sample technique method used in this study is simple random sampling. This random sampling gives the entire population in Batam City the opportunity to participate in this research. The method of collecting the amount of data or the number of respondents in general depends on the number of questions or the number of indicators multiplied by 5 (five) according to Hair, Black, Babin, and Anderson (2014). Based on these calculations, the minimum number of respondents needed is 290 respondents where the number of indicators (58 indicators) multiplied by 5 (five). To anticipate respondents who experience disability or invalid, a questionnaire via Google form will be distributed to 300 respondents.

This research model uses multiple linear regression (multiple linear regression). Respondent data collected will be analyzed using "SPSS or Statistical Product and Service Solutions" software version 21.

\section{RESULTS AND DISCUSSION}

Of the 300 scattered respondents, 4 of them experienced outliers and a total of 296 respondents were processed.Judging from the number of respondents by sex, the majority of sex in this study were women with a percentage of $65.5 \%$. The majority of respondents in this study are also still single with a percentage of $99 \%$. The majority of ages also range in age from 20-24 with a percentage of $90.2 \%$ and also as much as $80.7 \%$ are already working. The majority of education is SMA/ K as much as 78.7 and the majority of the population is Lubuk Baja District with a percentage of $40.2 \%$.

Based on the outlier test results on the respondent data in this study, the outlier test stated that there were 4 (four) data that experienced irregularities or errors. Z-score of 4 (four) data does not meet the criteria for criteria that exceeds the number 3 and reduces the number -3 .

In testing the validity, financial literacy leaves 8 (eight) indicators out of 10 (ten) indicators. The remaining 6 (six) financial behaviors indicators out of 10 (ten) indicators. Financial stress variables do not experience a lack of indicators in testing validity which indicates that all financial stress indicators are said to be valid. Financial attitude experienced a reduction of 8 (eight) valid indicators. Financial socialization agents, there are 6 (six) indicators remaining from the 7 (seven) initial indicators. Financial well being, there are 9 (nine) indicators remaining from 10 (ten) indicators.In reliability testing, all variables have met the requirements for further testing.

The results of the normality test research produce significant values in the Kolmogorov Smirnov table with a value of 0.795 and Asymp values. Sig. (2tailed) of 0.553 or more than 0.05 so that 
it qualifies as a study with normal distribution.

The results of multicollinearity testing produce financial attitude, financial socialization agents, financial stress, financial literacy, financial behavior variables showing a VIF value of five independent variables have a value of less than 10.

Heteroscedasticity test results produce variable financial literacy shows a glacier value of 0.317 , financial behavior of 0.062 , financial stress of 0.113 , financial attitude of 0.906 and financial socialization agents of 0.408 .

$\mathrm{F}$ test results produce a significant value with a value of 0,000 which indicates that the independent variables such as financial literacy, financial behavior, financial stress, financial attitude, and financial socialization agents have a significant simultaneous relationship with dependent variables, namely financial well being.

$\mathrm{T}$ test results produce financial literacy has a significant value of 0,000 , financial behavior significant value of 0.203 , financial stress with a beta value of -0.168 and a significant value of 0.011 , financial attitude significant value of 0,000 and financial socialization agents significant value of 0,000 .

Financial literacy has a significant positive relationship and influence because having the ability to manage finances well and being able to take financial decisions well can affect one's financial well being.

Financial behavior does not have a direct influence on financial well being because there must be a forerunner that encourages financial behavior to be able to influence one's financial well being.

Financial stress has a significant negative effect on one's financial well being because someone who is experiencing financial pressure will have difficulty experiencing and carrying out the financial well being situation.
Financial attitude has a direct influence that is able to influence one's financial well being because having a target and good financial planning can improve one's financial well being

Financial socialization agents can influence a person's financial well being by providing knowledge or knowledge about finance from both external and internal factors of one's association

\section{CONCLUSIONS}

The conclusion of this study is to formulate that financial attitude, financial socializationagentsand financial literacy have a significant positive relationship on financial well being. Financial literacy has a significant positive relationship because having the ability to manage finances and make good financial decisions can affect one's level of financial well being. With the financial thoughts and targets in the long term which is the attitude of the financial attitude will also increase the level of one's financial well being. Financial socialization agents will affect one's financial well being by influencing opinions and knowledge about finance. Financial behavior is considered not to have a significant positive effect because there must be a forerunner who is able to influence financial behavior in order to be able to influence one's financial well being. Financial stress is considered to have a significant negative effect because someone who is experiencing financial stress tends not to be able to achieve financial well being well.

\section{RECOMMENDATIONS}

Research is still far from perfection due to the still minimal number of respondents compared to the population in Batam and also the influence of the amount of time used is less long and also this study is only done alone.

Some other variables that can be used can be in the form of debt management, financial confidence and 
attitude towards saving can be used as an independent variable to test whether the variable is also able to influence financial well being. In addition, further researchers can also categorize the respondents more clearly based on the type of work or department.

\section{ACKNOWLEDGMENT}

In completing this research, the author is very grateful to Universitas Internasional Batam, which has provided much support.

\section{DAFTAR PUSTAKA}

Abdullah, N., Fazli, S. M., Mastura, A., \& Arif, M. (2019). The Relationship between Attitude towards Money, Financial Literacy and Debt Management with Young Worker' $s$ Financial Well Being. Pertanika Journal of Social Sciences and Humanities, 27(1), 361-378.

Aboagye, J., \& Jung, J. Y. (2018). Debt Holding, Financial Behavior, and Financial Satisfaction. Journal of Financial Counseling and Planning, 29(2),208-217.

Adam, A. M., Frimpong, S., \& Boadu, M. O. (2017). Financial Literacy and Financial Planning: Implication for Financial Well-Being of Retirees. Business and Economic Horizons, 13(2), 224-236.

Ali, A., Rahman, M. S. A., \& Bakar, A. (2013). Financial Literacy and Satisfaction in Malaysia: A Pilot Study. International Journal of Trade, Economics and Finance, 4(5), 319-324.

Azman Mohamed, N. (2017). Financial Socialization: A Cornerstone for Young Employees' Financial WellBeing. Reports on Economics and Finance, 3(1), 15-35.

Badan Pusat Statistik Kota Batam. (2018). Kota Batam Dalam Angka 2018. In Badan Pusat Statistik Kota Batam/ BPS-Statistics of Batam
Municipality.

Badan Pusat Statistik. (2018). Statistik Indonesia 2018. In Badan Pusat Statistik/BPS-Statistics Indonesia. Badan Pusat Statistik/BPS-Statistics Indonesia.

Bilal, M., \& Zulfiqar, M. (2016). Financial Wellbeing is the Goal of Financial Literacy. Research Journal of Finance and Accounting, 7(11), 94-103.

Chikezie, O. C., \& Sabri, M. F. (2017). The Financial Well-Being of Nigerian Students in Universiti Putra Malaysia. Journal of Education and Social Sciences, 6(2), 287-294.

Consumer Financial Protection Bureau. (2015). Financial Well Being: The Goal of Financial Education. Consumer Financial Protection Bureau, (January), 48.

Coşkuner, S. (2016). Understanding Factors Affecting Financial Satisfaction: The Influence of Financial Behavior, Financial Knowledge and Demographics. Imperial Journal of Interdisciplinary Research, 2(5), 377-385.

Damian, L. E., Negru-Subtirica, O., Domocus, I. M., \& Friedlmeier, M. (2019). Healthy Financial Behaviors and Financial Satisfaction in Emerging Adulthood: A Parental Socialization Perspective. Study of Emerging Adulthood and SAGE Publishing, 1-7.

Davis, K., \& Runyan, R. C. (2016). Personality Traits and Financial Satisfaction: Investigation of a Hierarchical Approach. Journal of Financial Counseling and Planning, 27(1), 47-60.

Falahati, L., \& Sabri, M. F. (2015). An Exploratory Study of Personal Financial Well Being Determinants: Examining the Moderating Effect of Gender. Canadian Center of Science and Education, 11(4), 33-42.

Falahati, L., Sabri, M. F., \& Paim, L. H. J. (2012). Assessment a Model of 
Financial Satisfaction Predictors : Examining the Mediate Effect of Financial Behaviour and Financial Strain. World Applied Sciences Journal, 20(2), 190-197.

Hair, J. F., Black, W. C., Babin, B. J., \& Anderson, R. E. (2014). Multivariate Data Analysis. In Pearson Education Limited 2014.

Hasibuan, B. K., Lubis, Y. M., \& HR, W. A. (2018). Financial Literacy and Financial Behavior as a Measure of Financial Satisfaction. Advances in Economics, Business and Management Research (AEBMR), 46, 503-507.

Khan, M. T., \& Akhter, A. (2018). Impact of Financial Knowledge of Women on the Household Financial Well Being. Journal of Management, 5(3), 80-88.

Kirbis, I. S., \& Galic, Z. (2016). Relationship Between Financial Satisfaction and Financial Literacy: Exploring Gender Differences. ResearchGate, 165-185.

Mahdzan, N. S., Zainuddin, R., Sukor, M. E. A., Zainir, F., \& Ahmad, W. M. W. (2019). Determinants of Subjective Financial Well - Being Across Three Different Household Income Groups in Malaysia. Social Indicators Research, 1-28.

Moga Dass, L., \& Fazli Sabri, M. (2017). The Financial Status and Factors Affecting Personal Well---Being Among Urban Poor in Kuala Lumpur. Malaysian Journal of Social Sciences and Humanities, 2(1), 21-39.

Mokhtar, N., \& Husniyah, A. R. (2016). Determinants of Employee Perception on Financial Well-Being. Malaysian Journal of Consumer and Family Econimics, 27-52.

Mokhtar, N., \& Husniyah, A. R. (2017). Determinants of Financial WellBeing among Public Employees in
Putrajaya, Malaysia. Pertanika Journal of Social Sciences and Humanities, 25(3), 1241-1260

Montalto,C. P., Mcdaniel, A., \& Baker, A. R. (2018). College Student Financial Wellness : Student Loans and Beyond. Journal of Family and Economic Issues, O(0), 0.

Mutang, J. A., Wider, W., Bahari, F. B., \& Madlan, L. (2017). The Effect of Finacial Literacy and Attitude Towards Credist Cards on Financial Well Being among Undergraduates in East Malaysia. The Social Sciences, 12(7), 1143-1150.

Nandan,T., \&Saurabh, K. (2019). Role of Financial Knowledge, Financial Socialisation and Financial Risk Attitude in Financial Satisfaction of Indian Individuals. International Journal of Indian Culture and Business Management, 18(1), 104122.

Osman, Z, Madzlan,E.M., and Ing, P. (2018). In Pursuit of Financial Wellbeing: The Effects of Financial Literacy, Financial Behaviour and Financial Stress on Employees in Labuan. International Journal of Service Management and Sustainability, 3(1), 56-94.

Otoritas Jasa Keuangan. (2016). Survei Nasional Literasi dan Inklusi Keuangan 2016. Otoritas Jasa Keuangan, 6(2), 103.

Otoritas Jasa Keuangan. (2017). Strategi Nasional Literasi KeuanganIndonesia (Revisit 2017). In Otoritas Jasa Keuangan (pp. 199).

Parcia, R. O., \& Estimo, E. T. E. (2017). EmployeesFinancial Literacy, Behavior,Stress and Wellness. Journalof Human Resource Management, 5(5), 78-89.

Radjab, E., \& Jaman, A. (2017). Metodologi Penelitian Bisnis. In Lembaga Perpustakaan dan Penerbitan Universitas Muhammadiyah Makassar. 
Riitsalu, L., \& Murakas, R. (2018). Subjective financial knowledge , prudent behaviour and income The predictors of financial well-being in Estonia. International Journal of Bank Marketing.

Sabri, M. F., Cook, C. C., \& Gudmunson, C. G. (2012). Financial Well-Being of Malaysian College Students. Asian Education and Development Studies, 1(2), 153-170.

Sabri, M. F., \& Falahati, L. F. (2013). Predictors of Financial Well-Being among Malaysian Employees: Examining the Mediate Effect of Financial Stress. Journal of Emerging Economies and Islamic Research, 1(3), 1-16. Retrieved from

Sabri, M. F., Paim, L., Falahati, L., \& Masud, J. (2013). Determinants of Employees' Financial Well-Being: The Moderation Effect of Work Sectors. Malaysian Journal of Consumer and Family Economics, 16, 91-106.

Sabri, M. F., \& Zakaria, N. F. (2015). The Influence of Financial Literacy , Money Attitude , Financial Strain and Financial Capability on Young Employees' Financial Well-Being. Pertanika J. Soc. Sci, 23(4), 827848.

Sawitri, N. N. (2018). Behavior in Managing Revenue to Achieve Financial Satisfaction. 34(86), 1274-1291.

Setiyani, R., \& Solichatun, I. (2019). Financial Well-being of College Students: An Empirical Study on Mediation Effect of Financial Behavior. International Conference on Economics, Education, Business and Accounting, 451-474.

Shaulskiy, S., Duckett, K., Phillips, L. K., \& McDaniel, A. (2016). Exploring Differences in College Student Financial Wellness by Institution Type Exploring Differences in College Student Financial Wellness by Institution Type. Journal of Student Affairs Research and Practice ISSN:, 52(3), 250261.

Tie, S. C., \& Nizam, I. (2016). Determinants of Financial WellBeing for Generation $\mathrm{Y}$ in Malaysia. International Journal of Education, Learning and Training, 1(1), 36-52.

Wahab, N. N., \& Yaacob, Z. (2018). Strategy For Financial Wellbeing among Public Servants in Malaysia. Journal of Techno Social, 10(2), 5059.

Woodyard, A. S., \& Robb, C. A. (2016). Consideration of Financial Satisfaction: What Consumers Know, Feel and Do from a Financial Perspective Consideration of Financial Satisfaction: Journal of Financial Therapy, 7(2), 41-61. 8/1944-9771.1102

Xiao, J. J., Chen, C., \& Chen, F. (2013). Consumer Financial Capability and Financial Satisfaction. Springer Science+Business Media Dordrecht, 113(3).

Yap, R. J. C., Komalasari, F., \& Hadiansah, I. (2016). The Effect of Financial Literacy and Attitude on Financial Management Behavior and Satisfaction. International Journal of Administrative Science \& Organization, September 2016, 23(3), 140-146.

Younas, W., Javed, T., Kalumuthu, R., Farooq, M., \& Rehman, F. K. ur R. (2019). Impact of Self-Control , Financial Literacy and Financial Behavior on Financial. The Journal of Social Sciences Research, 5(1), 211-218.

Zainul Arifin, A. (2018). Influence Factors Toward Financial Satisfaction with Financial Behavior as Intervening Variable on Jakarta Area Workforce. European Research Studies Journal, 21(1), 90-103. 